\title{
The Concept of Truth Regime ${ }^{1}$
}

\author{
LORNA WEIR
}

\begin{abstract}
Truth regime" is a much used but little theorized concept, with the Foucauldian literature presupposing that truth in modernity is uniformly scientific/quasi-scientific and enhances power. I argue that the forms of truth characteristic of our present are wider than Foucault recognized, their relations to power more various, and their historicity more complex. The truth regime of advanced modernity is characterized by multiple, irreducible truth formulae that co-exist and sometimes vie for dominance. A truth formula stabilizes a network of elements: a relation between representation and presentation (words and things), truth and non-truth, and the place of the subject in discourse. Our contemporary truth regime comprises radically heterogeneous truthful knowledges - science, governance, religion/politics, and common culture - that have distinct histories and relations to power.
\end{abstract}

Résumé. L'expression " régime de la vérité » est un concept très utilisé mais à l'égard duquel peu de théories ont été émises, les traits de Foucault supposant que la vérité à l'époque moderne est uniformément scientifique ou quasi scientifique et qu'elle donne plus de pouvoir. Je suis d'accord que les formes de vérités qui sont caractéristiques de notre époque sont plus larges que celles reconnues par Foucault, leurs relations au pouvoir plus nombreuses et leur historicité plus complexe. Le régime de la vérité de la modernité avancée se caractérise par de multiples et irréductibles formules de vérités qui coexistent et parfois rivalisent. Une formule de vérité stabilise un réseau d'éléments : une relation entre représentation et présentation (mots et choses), la vérité et la non vérité et la place du sujet dans le discours. Notre régime de vérité contemporain est composé de connaissances vraies radicalement hétérogènes - science, gouvernance, religion/ politique et la culture commune - qui ont des histoires et des relations distinctes à l'égard du pouvoir.

1. I am indebted to my colleague Brian Singer for his careful comments which greatly benefited this article. Eric Mykhalovskiy and Frank Pearce were generous in giving the manuscript close readings. The $C J S$ reviewers requested some needed corrections. Pam Shime suggested the example of "Intelligent Design." I thank you all for your collegial help. 
T ruth regime is a much-used but little theorized concept. A pithy phrase that Foucault (2000b) introduced in a single interview during 1976, "truth regime" appears to have been subsequently abandoned by him, only to be repeated by many others without further conceptualization. A more robust conceptualization of truth regime is needed to acknowledge that the truth practices of contemporary societies are more heterogeneous than Foucault's overemphasis on scientific and quasi-scientific truth in modernity. Contemporary forms of truth are wider than Foucault recognized, their relations to power more various, and their historicity more complex.

Following the trajectory of Foucault's last work on the multiplicity of co-existing truth games in ancient Greece and Rome, I suggest that truth in modernity is not singular but multiple in its types, which I term "truth formulae." Truth formulae stabilize a relation across a set of elements: between representation and presentation - words and things as Foucault put it in The Order of Things (1989b [1966]), truth and nontruth, and the place of the subject - both the enunciatory (s/he who may speak truth) and the enunciated (the subject within the text). Power is not an intrinsic criterion of truth formulae; rather, truth formulae acquire effects of power through their attachment to specific dispositifs (power apparatuses such as discipline and sexuality) in a truth regime. Truth formulae in contemporary societies have variable relations with power rather than the single function of assisting power.

I take "truth regime" as a "general politics of truth" in the sense Foucault (2000b:131; 1994a:158) first proposed: "Each society has its regime of truth, its 'general politics' of truth - that is, the types of discourse it accepts and makes function as true." Foucault sketched several criteria of truth regimes: techniques that separate true and false statements; how true and false are sanctioned; the status given those who speak that which is recognized as truth. The concept of truth formula introduces another level of abstraction into the concept of truth regime: how things are made to appear, how they come to be represented, and how the relation between things and words is formulated. Truth has many possible nontruthful others, not solely falsehood, and truth's subject is not simply s/ he who speaks, but the subject in the text. The techniques, sanctioning, and status of the truth-producing subject suppose a prior solution to these epistemological questions, and these have taken many historical forms.

The truth regime of contemporary societies is composed of multiple truth formulae, not simply scientific and quasi-scientific truth. The contemporary truth regime contains discourses formed at differing historical moments. Instead of superseding each other historically, discourses with irreducible truth formulae co-exist in our present. In our contemporary 
truth regime, discourses of truth may enter into stable relations, or may engage in contests for domination.

Social scientists have returned to the question of values and ethics after a long lapse in which they were doubly discredited. Critical social scientists, influenced by Marxism, regarded theorizing values and ethics as purist ideology. This was partly a resistance to structural functionalism, which explained the production of social order by homogenous, coherent values and norms; social actors were said to orient action to the reproduction of values. Garfinkel and Goffman cut their sociological teeth rejecting this conceptualization of social action (Heritage 1984:75-103), but it was not until several decades later that post-Marxist critical sociologies gave ethics and normative social action substantive consideration rather than ideological critique. Current social scientific work on values ranges across topics such as cosmopolitanism (Calhoun 2007), bureaucratic organization and ethics (Bauman 1989), truth in the European Enlightenment (Osborne 1998), the normative bases for postsovereign politics (e.g., Fraser 2005), and a general theory of values (Joas 2000). My analysis of truth regimes and truth formulae in advanced modernity contributes to this contemporary research trajectory, which indeed has a long history in the social sciences. My analysis of irreducible conflict among truth formulae is reminiscent of Weber's value spheres in modernity, such as science and politics. Weber argued that value spheres have their own autonomous and irreconcilable principles of ordering their own values; the value spheres rest on no foundational values that might provide a coherent organization of morality in modernity. Here, however, the focus is on the single value of truth and relations among its diverse forms rather than relations across differing value spheres. Unlike Weber's concept of value spheres, this investigation does not provide a general theory of values in modernity.

I begin with a short outline of Foucault's problematic of truth, turning in the following section to the concept of truth formula and its heuristic use in distinguishing differing types of truth: veridical, governmental, symbolic, and mundane. I illustrate the significance of these distinctions among truth formulae with a contemporary empirical example, examining the struggle between natural scientists and the Christian right in the United States over the concept of "intelligent design." The argument is that "intelligent design" may be conceptualized as a contest between two distinct truth formulae - veridical and symbolic. The analysis of "intelligent design" displays our contemporary truth regime as characterized by conflict among truth types with fundamental epistemic differences and historicities. 


\section{Foucault's Problematic of Truth}

The problematic of truth crosscuts Foucault's work from Birth of the Clinic (1973 [1963]) to his final writings. From his early "archaeological" work on truthful statements in theoretical knowledge, to his middle period "genealogical" writings on truth and power, to his last publications on truth-telling and the subject, truth is a key theme. He did not ask what truth is or should be, that is, his question was neither metaphysical nor normative. Rather, following Nietzsche, he approached truth as an historical question to be analyzed in terms of its practices and effects.

Foucault's problematic of truth was constructed in dialogue with the 20th century French school of the historical epistemology of science, which he used to refute the existentialism and phenomenology of the 1950s. ${ }^{2}$ From its beginnings in the work of Gaston Bachelard during the 1920s, historical epistemology maintained that scientific knowledges are normatively oriented to the production of truth. Georges Canguilhem (1988:11) clarified Bachelard's position: "By truthful Bachelard does not mean that scientific laws simply tell a truth permanently inscribed in objects or intellect. Truth is simply what science speaks.... A science is a discourse governed by critical correction," that is, scientific knowledge is "veridical." Historical epistemologists conceptualize scientific truth as provisional, with science characterized by internal rupture as it overturns previously accepted theories and cosmologies. ${ }^{4}$ The orientation of scientific work to truth unsettles scientific discourse rather than leading to the constitution of cumulative, permanent truths. The quality of being a self-correcting discourse normatively oriented to truth, Bachelard (1977) and Canguilhem (1988) argued, is what separates scientific discourse from what they variously call "common knowledge," "common sense," or "common culture" (using these terms synonymously), based on the acceptance of the intuitively obvious. Bachelard maintained that early modern science was constituted through a science from immediate

2. In Foucault's (1989a:8) "Introduction" to the second edition of Georges Canguilhem's The Normal and the Pathological, he noted a cleavage in post-World War II French philosophy and social theory between "the line that separates a philosophy of experience, of sense and of subject from a philosophy of knowledge, of rationality and of concept. On the one hand, one network is that of Sartre and Merleau-Ponty; and then another is that of Cavaillès, Bachelard and Canguilhem." Foucault identified his own work with the second lineage, that is, the historical epistemology of science.

3. For a commentary on Canguilhem's concept of truth, see Balibar (1993).

4. Balibar (1993:68-9) argues that Canguilhem provides as well for an ongoing process of the "ideologization" and "deideologization" of the sciences. 
knowledge and everyday experience, which were replaced in scientific knowledge by experiment and abstract theory (Tiles 1984:53-57).

Foucault followed the historical epistemology of science in examining learned discourses rather than common knowledge (Foucault 1976b:220; Dreyfus and Rabinow 1983:47-48), that is "serious" statements that are rare and repeatable, a specific range of practices "more or less regulated, more or less conscious, more or less finalized" (Foucault 1998a:465). As in historical epistemology, Foucault treated common knowledge as the external other of the rare and repeatable, making it in effect of no theoretical interest, its substance historically inert because not directed to the production of truth.

Foucault (1994d:843-844, cited in Davidson 2001:196) distinguished his problematic from historical epistemology by fashioning a new domain of analysis: the area of savoir (theoretical knowledge) falling between opinion and scientific connaissances such as biology or physics. ${ }^{5}$ Theoretical knowledges (savoirs) lack the degree of formalization of the scientific disciplines (connaissances), but are similar to the sciences in being oriented to the production of truthful practices and statements, their study being a "history of 'veridictions,' understood as the forms according to which discourses capable of being declared true or false are articulated concerning a domain of things" (Foucault, 1998a:460). Thus, for historical epistemologists, knowledge is divided dyadically into science and common sense, whereas for Foucault knowledge has a triadic form: scientific disciplines (connaissances), theoretical knowledges (savoirs), and common knowledge.

In a 1978 exchange with a group of eminent French historians ${ }^{6}$ after the publication of Discipline and Punish (1979 [1975]), Foucault clarified his aims and approach to the writing of history. This discussion is

5. In his last writings Foucault (1994b:16; 2001:171) insisted that his object of inquiry consisted of savoirs such as economics, criminology, and medicine: knowledge forms that orient their statements to the standard of truth. As Delaporte (1998), Davidson (2001:194-196), and Dupont (2006) have argued, Foucault differed from historical epistemologists in taking as his object of investigation the savoirs of expertise rather than scientific connaissances.

In the present context, connaissance refers to the knowledge of a scientific discipline such as biochemistry or microbiology. Savoir means knowledge in general, including scientific knowledge overall - the combined knowledge of the separate connaissances scientifiques. For discussion of Foucault's usage of savoir and connaissance in The Archaeology of Knowledge, see the translation note by A.M. Sheridan-Smith: Foucault 1976a [1969]:15, Fn. 2

6. The following participated in the 1978 seminar: Maurice Agulhon, Nicole Caston, Catherine Duprat, François Ewald, Arlette Farge, Alexandre Fontana, Michel Foucault, Carol Ginzburg, Remi Gossez, Jacques Léonard, Pascal Pasquino, Michelle Perrot, Jacques Revel. The meeting was convened by the 
helpful to historians and social scientists trying to understand the place of truth in Foucault's thought. The exchange was organized around a position paper written by the historian Jacques Léonard (1980), “L'Historien et le philosophe: À propos de Surveiller et punir: naissance de la prison" to which Foucault (1994b [1980]) gave a written response, "La Poussière et le nuage." The first half of Léonard's paper listed a number of stock arguments that historians then and now use to dismiss Foucault's work as abstract philosophy. Léonard (1980:12) reported other historians as saying that Discipline and Punish exaggerated the degree of normalization and rationalization present in 19th century France, and minimized the extent to which revolts, insurrections, and revolutions indicated that the French had not been disciplined (Léonard 1980:16). The "dust" of facts found in archival research belied the thesis of massive normalization (Léonard 1980:15). Moreover, Foucault's abstractions disguised the place of agency and the actor in making history. Foucault (1994b [1980]:11-13) responded that his was not a history dedicated to the study of a period, but rather to the analysis of a problem: how incarceration came to dominate the French penal system in 1791. The historian, according to Foucault (1994b [1980]:14-15), studies the prison, delinquency, or French society in a given period, whereas he himself frames inquiry in terms of the history of rational practices, specified in the particular case of Discipline and Punish as the history of "punitive reason" (raison punitive). More generally, his project is to understand what significance rational practices based on the division true/false have had within Western history (Foucault 1994c:29-30).

Foucault pointedly remarked that his work did not seek to analyze the "real in prisons," while maintaining that problematizations have "effects in the real" at the level of institutional practice, individual behaviour, and perception (Foucault, 1994c [1980]:28-29). The relation between "raison punitive" and social institutions is one of simplification and uneven distribution, found at some institutional sites, but not others. What Foucault called the "rational schemas" (Foucault 1994c [1980]:27-28) of the prison or hospital are "explicit programmes ... to organize institutions, to design spaces and regulate behaviour." These programs do not stand outside "the real" without effect. However, he cautioned that it is an error to read disciplinary power (a rationalized schema of power) as resulting in a totally disciplined society (Foucault, 1994b [1980]:15-6).

The gap between the disciplinary and the disciplined society is an aporia in Foucault's thought; he cannot provide an account of how it might arise. To address the aporia would require positing social pro-

Société d'histoire de la révolution de 1848. A seminar was subsequently held, followed by a report of the discussion (Foucault 1994c [1980]). 
cesses that operate with a logic in excess of rare discourses and power apparatuses. Truthful practices act on kinship, everyday life, and common culture, but these have their own immanent principles of ordering not fully subsumed by rare discourses and power apparatuses. Implied here is a reconsideration of Foucault's original refusal of phenomenology and existentialism. The aporia of the disciplinary and the disciplined has consequences for Foucauldian scholarship that are logically prior to accounting for resistance.

Foucault's writings of the 1970s famously posited an intrinsic relation between truth and power, arguing that savoirs such as economics and philology and the dispositifs (power apparatuses - a new critical concept not found in his earlier writings - see Brenner 1994) such as discipline/sexuality contained much nonscientific knowledge and used the register of truth to obfuscate their relation to power (Foucault 1976b [1971]:220). In the works of his middle, genealogical, period, he famously argued that power enters into the formation of knowledges/savoirs as the acceptability of their statements is secured in part politically (Han 2002:120). As many have noted (e.g., Ansell-Pearson 1995), there is a Nietzschean cast to Foucault's work of the 1970s and 1980s that was absent from Bachelard or Canguilhem: truth is bloody rather than innocent, and genealogy the study of "the endlessly repeated play of dominations" (Foucault 1998b:377).

During the "Truth and Power" interview in June 1976, Foucault (2000b; 1994a) introduced the notion of "truth regime" (régime de véri$t e ́)$ in his written response to the final interview question which concerned the role of intellectuals in contemporary political activism. Régime de vérité appears in two passages towards the end of the interview where Foucault argued that truth and power have had an intrinsic relation in the history of the West. In the first passage, Foucault (2000b:131; 1994a:158) surprisingly introduced "truth regime" as a transhistorical concept, providing criteria for its analysis. This passage reproduces some of the analytic criteria formulated in the Archaeology of Knowledge for the analysis of what he there called "discourse formations." The second passage referring to "truth regime" in the 1976 interview famously asserted a circular relation between truth and power:

"Truth" is linked in a circular relation with systems of power that produce and sustain it, and to effects of power which induce and which extend it - a "regime" of truth. (Foucault 2000b:132; 1994a:160).

And then, having written what was to become one of the most celebrated passages in his work, Foucault abandoned "truth regime" forever, leaving its formulation in a brilliant protoconceptual state. 
It is clear from the context of his remarks in "Truth and Power" that Foucault formulated "truth regime" as a way of thinking through the position of natural scientists as intellectuals in modernity, and the destabilization of this model of the intellectual. He treated truth as homogenous, differentiated only in relation to the position of intellectuals: "universal" intellectuals who speak the law and "specific" intellectuals who speak from the perspective of particular locations. More generally, Foucault's writings of the 1970s partitioned truth by dispositif (power apparatus) such as discipline, governance, and security, but treated truth as having a uniformly scientific or quasi-scientific form. Truth in modernity has, he asserted, everywhere been implicated in power.

Foucault's final writings on Ancient Greek, Roman, and early Christian history, following Hadot's work on the place of spiritual practices in ancient philosophy, sought to understand the place of truth in Ancient Greek and Roman culture, examining what Foucault called "techniques of the self" and other truth games. The "techniques of the self" were forms of rigorous self-cultivation through which the subject tried to establish a personal relation to universal truth. These ancient practices of self were of interest to Foucault because he saw them as enabling negotiation between truth/the subject and power. In the ancient practices of the self, truth did not simply duplicate power; the two terms contained the possibility of being at a distance from each other.

Foucault suggested that, with modification, ancient practices of the self could be applied in our time, and historians of the present have documented a wide range of techniques of the self in contemporary practice. Their significance for the conceptualization of truth and power in modern truth regimes was never explored by Foucault, who did not consider the possibility that modernity might have differing, co-existing truth types that circulate across truth games, nor that truth might do anything other than enhance power in modernity.

\section{Truth Formulae}

The large and lively Foucauldian literature on governance, discipline, and security shows little analytic interest in truth, supposing it as a condition of inquiry. Truth, it would appear, has one stable form found across all power/knowledge relations. One significant exception to this pattern can be found in studies of contemporary truth-telling and techniques of the self (Taylor and Vintges 2004), notably the work of Mariana Valverde $(1998 ; 2004 a)$. Valverde has analyzed truth-telling in contemporary feminist practice and Alcoholics Anonymous meetings where participants 
speak truth about their own experience, an activity they perceive as requiring courage.

The contemporary heterogeneity of truth, and the contestations in the name of truth across science, religion, governance, and everyday life, might initially be approached through the concept of truth games. A particular truth game, Foucault proposed, can be identified through a series of questions (Foucault 2001:169-170). Who is considered qualified to speak the truth? From where do they speak and to whom? Where is the addressee? What topics are prescribed? What is the purpose of the truth game? How is truth practised? What is the relation between the truthful practice and power? As a concept, truth game directs attention to truth as an historical practice. The number of truth games is open as the games are subject to constant self-transformation:

With regard to these multiple games of truth, one can see that ever since the age of the Greeks our society has been marked by the lack of a precise and imperative definition of games of truth which are permitted to the exclusion of all others. In a given game of truth, it is always possible to discover something different and to more or less modify this or that rule, and sometimes even the entire game of truth. (Foucault 1997:297)

Truth games are characterized by the potential for constituting new truth games.

Foucault's conceptualization of truth game distinguishes truth types at the level of person-to-person interaction, which Foucault termed "activity" - identifying who is speaking about what truth to whom and where. However, to inquire into the distinction between scientific truth and truthful practices one must do more than ask questions about social interaction. The concept of truth game does not direct attention to truth's opposites nor to more abstract questions about how words and things are culturally constituted. It is to this level of abstraction that we must turn to characterize our contemporary practices of truth in science, government, religion, and common sense.

The multiplicity of truth games circulates a small number of truth formulae that are formed from the relations between presentation and representation, the relations between truth and non-truth, and the place of the subject in written discourse and speech. Advanced modernity is characterized by the coexistence of several truth formulae - veridical, symbolic, governmental, and mundane - that result from combinations of these fundamental elements. Presentation concerns how things are rendered present/made available for knowledge. Representation implies a second stage, where, once presented, things are given again in speech, writing, the visual arts, and other signifying practices. The second crite- 
rion of truth formulae addresses the relation between truth and non-truth, with truth variously defined against lies, error, or incoherence. But truth must always take an opposite; it has an antithetical structure, its meaning determined by the antithesis from which it must be continually distinguished. Lastly, the place of the subject directs analysis to two differing subjects: the enunciatory and the enunciated. The enuniatory subject is $\mathrm{s} /$ he who produces truthful discourse in speech, writing, and/or action. The place of the subject in the discourse/speech also references the relation between the subject in the text and his/her place within the truthful discourse. This is the enunciated subject. When a parent reads The Three Bears to her/his children, the parent is the enunciatory subject; the enunciated subjects are the Mama, Papa, and Baby Bears.

The veridical formula of truth found in the sciences assumes things are immediately present. Its presentations are conceived as external to and preceding representation. Knowledge represents things and does not have an immediate effect on their presence as given. Veridical truth is characterized by the absence of an enunciated subject whose temporal and spatial coordinates organize the account (Schutz 1962:222-3). The enunciatory subject of the veridical truth formula is constituted through an epistemological break with common knowledge that displaces the knowing subject of everyday experience and her intuitively self-evident world. In veridical truth the distinction between truth and non-truth appears as an antithesis of truth and error. Scientific practice is oriented to uprooting the false which it continually produces: a restless "discourse of critical self-correction" to use Canguilhem's (1988:11) expression.

In The Discourse on Language Foucault (1976b:218) mentioned another form of "true discourse," one that existed during the 6th century $\mathrm{BCE}$, a practice of truth that pre-existed the formation of philosophy. In an analysis that appears to be indebted to Marcel Détienne's The Masters of Truth in Archaic Greece (Han 2002:94-95), Foucault argued that "true discourse" consisted of highly ritualized, performative speech done by poets. To be "true," poetic speech was required to follow ritual procedures so as to fulfill its functions of being poetic, prophetic, and dispensing justice. One might further note that the Sophists displaced this poetic form of truth, disconnecting truthful speech from ritual and the occupational status of poet, making truth accessible to anyone with sufficient education and money to buy the services of the philosopher, a position for which they were to be roundly criticized by Plato as selling truth (alethia) in the marketplace.

The symbolic formula of truth did not die with Hesiod in Archaic Greece, as Foucault knew from Hadot's (1995) work on the relation between spiritual exercises and ancient philosophy. So too, the Christian 
understanding of truth as God's revelation to humanity, with the consequent necessity of human exegesis to recover and interpret that initial word, has long been part of Western history. The symbolic formula supposes things can exist in the invisible without being present and can only be made present by being represented. Representation in symbolic truth manifests what is not present, making visible that which cannot be seen but which is thought to exist. Presentation is constituted through representation. What cannot be seen prior to representation may be invisible in a number of ways; representation may render present the transcendent, or the out-of-sight/perception. It should be noted that the symbolic is a much broader category than religion, applying also to contemporary politics where the democratic sovereign, the people, does not pre-exist its representation (Singer and Weir 2007:454-5). The symbolic formula provides sense, coherence, and order to that which is represented; nontruth takes the form of non-sense, incoherence, and/or disorder. The subject enunciating symbolic truth is necessary to and implicated in that which is being presented; the subject enunciated through symbolic truth, whether citizen or saint, is constituted in symbolic discourse or speech. The authorized speakers of symbolic truths may coincide with powerholders, as was the case with the absolute monarchs of the early modern period who made visible divine will and modelled temporal power on divine power (Singer and Weir 2007:453-4). These speakers may also diverge from those in the place of power; in which case, those authorized to speak symbolic truth may form a counterweight to those in political power.

The motley discourses of the savoirs share in the characteristics of both veridical and symbolic truth, a hybridized form I call governmental truth because theoretical knowledges such as economics and psychiatry are incorporated into governance: the management of conduct by authorities. Governmental truth is an epistemologically unstable form of truth unaware of its instabilities. It takes things to be immediately present, with presentation external to and pre-existing representation; it thus repeats the formula of veridical truth in this regard. However, governmental truth also acts to render things present by representing them. Thus the relation between presentation and representation in governmental truth is contradictory and open to contestation when the contradiction is made apparent, a focus of much work in critical sociology. Governmental truth also spans between veridical and symbolic truth in the relations it establishes between truth and non-truth. Non-truth appears simultaneously as error and disorder, although the savoirs do not have the discursive form of self-correction. Its opposite, truth, is then a practice of both correctness and coherence/order. As the savoirs contain political relevances and 
the categories of everyday experience, governmental truth often, though not invariably, is pronounced in the name of an enunciatory subject situated in a particular space and time - "this Commission," "this Inquiry," "this investigation" and so forth appear in the text as the enunciatory subject. Governmental discourses such as scientific psychology may also closely approximate the form of veridical truth, eliding the presence of the enunciatory subject in the plane of discourse. The position of the subject in governmental discourses is open to contest.

Within common knowledge, truth comprises a normative standard to which people regularly appeal. Lying forms mundane truth's opposite, as distinct from error or incoherence/disorder. Errors in everyday life don't form violations of truth unless they are interpreted as intentional. One is not usually accused of lying for forgetting to pick up milk on the way home from work. When we mistakenly do not forward an electronic attachment mentioned in the text of an email we rarely find ourselves faced with accusations of having lied. These lapses are sometimes interpreted to indicate normative flaws, particularly if they are frequent, but even these are not thought of as pertaining to truth. Yet some everyday speech acts do involve truth. Children are carefully and emphatically taught to speak the truth by their parents, teachers, and other authorities, admonished not to lie. "Tell me the truth!" "Don't lie to me!" say their parents who regularly pride themselves in skillfully lying in tax returns and to traffic police.

Common-sense knowledge has a normative dimension, with actors being held morally accountable for their actions and constantly evaluated by others. In common knowledge, mundane truth forms part of a practical morality of types. Mundane truth is a judgement applied to individual or collective speech, actions, and relations. An action may be typified as a lie, or a person may receive the reputation of honesty: a hermeneutic operation in which events are interpreted as signs of an invisible quality persisting across particular acts.

In the mundane formula of truth found in common sense, things are immediately present and their representation self-evident. Representation is fully adequate to presentation; a pipe is a pipe as it were. The enunciatory subject that speaks truth is located in the here and now of the interactive order. Unlike veridical truth, everyone has access to and must speak mundane truth. But common sense knows that those in power may lie, resulting in the separation of words and things. In this case, the subject as witness at a distance from the enunciations of power may demand a restoration of truth; the reunification of words and things, representation and presentation. Mundane truths pronounced by friends, family, and colleagues have other functions with respect to sovereignty and 
governmental authorities. They act as a resource for governmental truth, helping to fashion what Goffman (1961:125-170) called the "moral career" of those in disciplinary confinement and correction, made through the combining of expertise (such as psychiatry) with common knowledge (such as kinship).

The mundane formula of truth should not be taken as a human universal but as a cultural practice with a history. Nietzsche (1979:79-100) had much to say about the origins and practice of truth in our culture, and it may be that many centuries of Christian teaching implanted the value of truth in common knowledge, in the same fashion as the Aristotelian elements - earth, air, fire, water - became part of medieval European culture (Tiles 2004:56). Mundane truth is a secular cultural practice that resonates with the Christian idea of witnessing, which renders evident God's judgement. While the discussion of truth formulae presented here has been synchronic, examining each formula in its difference from the others, a diachronic study would show their historical formation and interaction. Steven Shapin's (1994:3-42) discussion of how the 17th century culture of truth among English gentlemen became part of early modern natural philosophy, assuring the veracity of experimental findings, shows that the veridical formula of truth was in part derived from a particular form of mundane truth: a gentleman's word was his honour.

Historians of the present have formed a strong and productive research trajectory concentrated on governmental savoirs such as accounting (Hopwood and Miller 1994), insurance (Ericson, Doyle, and Barry 2003), and psychology (Castel 1988; Rose 1990). ${ }^{7}$ With the notable exceptions of Hacking (2002) and Valverde (2004a; 2004b) there has been little interest in the topic of truth-telling and common knowledge. ${ }^{8}$ However, the sociology and anthropology of health has had an ongoing interest in the relation of biomedicine and lay knowledge/experience,

7. For an overview of publications on governmentality, see Rose, O'Malley, and Valverde 2006.

8. Explaining how it is possible for rare truth to become effective at the level of common knowledge has occupied some of the most productive contemporary Foucauldian-inspired scholars. These include Ian Hacking (2004:278) who wishes to explain "how the forms of discourse become part of the lives of ordinary people, or even how they become institutionalized and made part of the institutions at work." Nikolas Rose $(1999: 37,48)$ used the notions of "translation" and "network" from actor-network theory to transmit abstract, rationalized programs of governance into local conduct and organizations. Mariana Valverde (2004b) explored the understudied significance of common knowledge as opposed to expert evidence in legal proceedings. In order to understand how everyday life comes to be altered by power apparatuses, it is necessary to constitute common knowledge as a theoretical problem rather than the empty other of scientific and theoretical knowledge. 
although without an explicit analysis of truthful discourse (Good 1994; Kleinman 1988; Rapp 1999). The result has been to think that truth in our present has a single, invariant form found everywhere from contemporary techniques of the self to molecular genetics. Thus the heterogeneity of truth types has remained unproblematized. Ancient forms of symbolic truth are written out of the account, disappearing on the early modern horizon along with sovereign power, the monarch's head replaced with networks of technical governance and veridiction proceeding without limit in our present.

Pluralizing truth formulae is an analytic move useful in theorizing why contemporary governmental knowledges do not proceed to infinity, that is, how they are constrained. Another implication of the analysis provided here is that truth regimes may be composed of multiple and irreducible truth formulae in relations of stability and potential conflict. Lastly, contemporary truth formulae may have multiple relations to power rather than being locked in a circular relation with power.

\section{STrugGLES FOR INTERPRetive DoMinanCe}

Truth formulae are distributed across scientific knowledge, the savoirs, dispositifs (power apparatuses), and common sense. Contemporary veridical truth is situated in scientific knowledge, with symbolic truth in religion, politics, and law. ${ }^{9}$ Governmental truth is found in the theoretical knowledges (savoirs) and power apparatuses devised by authorities to manage both conduct and the relations between persons and things. Mundane truth appears in common knowledge. This distribution of truth formulae in the culture of advanced modernity should not be understood as transhistorical. Thus, for instance, the veridical formula of truth was invented in early modern science, while governmental truth dates to the anti-Machiavellian thought of the early modern period (Foucault 2000b). The inventions of veridical and governmental truth had profound effects on symbolic truth and on the symbolic more generally, effects constitutive of the modern truth regime. The concept of truth formulae thus partitions the concept of truth regime in a way that makes investigation of its historical formation possible.

In "Truth and Power" Foucault (2000b; 1994a) oversimplified the concept of truth regime by treating it solely in relation to science, rather than, for instance, demonstrating the dominance of veridical knowledge in relation to other forms of truthful knowledge. The truth regime of

9. This formulation of the symbolic is derived from the work of Claude Lefort (1986; 1988). For discussion see Singer and Weir (2007:253-4). 
modernity includes symbolic and mundane truth in addition to the scientific and governmental knowledges that have been the focus of Foucauldian research. To reconceptualize truth regime in this manner is to expand the scope of Foucauldian work, which was defined against common knowledge and, implicitly, the symbolic.

The analysis of truth regimes investigates the field of relations established among irreducible truth formulae, including their networks, stabilities, and rivalries. The truth regime of advanced modernity is characterized by struggles for domination among its truth-oriented knowledges. Veridical and symbolic truth have stable relations when the former is confined to science and the latter to religion, politics, and law, but they also enter into competition and struggle for interpretive dominance, as in the recent case of "intelligent design" in the United States.

The Darwinian theory of evolution has troubled Christians since the publication of The Origin of Species (1859). In the United States, a nonprofit organization known as the Discovery Institute is currently promoting what it calls "intelligent design." An antievolutionary concept, "intelligent design" maintains that "certain features of the universe and of living things are best explained by an intelligent cause, not an undirected process such as natural selection." ${ }^{10}$ Founded in 1990, the Discovery Institute furthers the Christian thought of C.S. Lewis. ${ }^{11}$ Its Centre for Science and Culture has led advocacy for "intelligent design," which is part of a broader initiative known as the "Wedge Strategy" that, in the Discovery Institute's own words, seeks "to defeat scientific materialism and its destructive moral, cultural and political legacies," substituting a "theistic understanding that nature and human beings are created by God." 12 The work of the Discovery Institute makes symbolic truth claims in order to bring coherence and meaning to what they regard as disorder wrought by science.

Since the Discovery Institute is well funded, with strong connections to the Republican Party and the powerful United States Christian evangelical movement, "intelligent design" has achieved widespread publicity. Borrowing the concept of "teaching the controversy" from radical pedagogy, proponents of "intelligent design" have attempted to have it legitimized as an alternative to the theory of evolution by requiring it be taught in the United States public school system as part of science

10.Http://www.discovery.org/csc/topQuestions.php\#Questions AboutIntelligent Design. Accessed August 2007.

11. Http://www.discovery.org/cslewis. Accessed August 2007.

12.For the text of the "Wedge" document and the Discovery Institute's response to criticisms made of it, see http://www.discovery.org/scripts/viewDB/index. php?command=view\&program $=C S C \& i d=2101$. Accessed August 2007. 
curricula. The Discovery Institute's connections to the Republican Party facilitated a series of interventions in science education, beginning with the Santorum Amendment to the 2001 federal education funding bill which would have obliged public schools to teach intelligent design as an alternative to evolutionary theory. ${ }^{13}$ The Santorum Amendment failed. Hearings at the Ohio State Board of Education (2002), the Kansas State Board of Education (2005), and the Kansas State Board Science Hearing Committee (2005) voted to require teachers to instruct students in both evolutionary theory and "intelligent design," although the Ohio ruling was challenged in the courts and subsequently turned down. ${ }^{14}$ In Tammy Kitzmiller, et al. V. Dover Area School District, et al., ${ }^{15}$ parents brought suit against a Pennsylvania school board regulation that instructors, prior to teaching the theory of evolution, read a statement defining evolution as contested by "intelligent design." The US federal court ruled in favour of the plaintiffs that "intelligent design" was religious rather than scientific, which meant that making its teaching compulsory violated the US Constitution.

"Intelligent design" succeeds "creationism," an earlier form of antievolutionism. Together they have challenged the Darwinian theory of evolution in the United States for several decades. "Intelligent design" claims to adhere to the standards of scientific truth and thus to meet evolutionary theory on its own grounds. The advocates of "intelligent design" hold that the universe is "irreducibly complex," that is, composed of mutually dependent functional parts, as demonstrated by the "fine-tuned" microphysics of the universe. It is said that the universe is of such "specified complexity" that its extraordinary patterns cannot be purely random but must instead serve some higher functional code. To the advocates of "intelligent design," only nonnatural causes can ultimately explain how natural complexity can work; the postulate of a transcendent deity is needed to pull it all together.

The scientific response to intelligent design has been to exteriorize it as nonscientific. ${ }^{16}$ Scientists and others critical of "intelligent design"

13.http://en.wikipedia.org/wiki/Santorum Amendment. Accessed August 2007.

14.For the changes to the Kansas Science Standards adopted by the Kansas State Board of Education see http://www.kansasscience2005.com/Draft_2 Changes_added_by_board_as_of_8905.pdf For the response by the National Academy of Sciences and the National Science Teachers Association see http://www.nationalacademies.org/morenews/includes/20051027.pdf. Accessed August 2007.

15.Tammy Kitzmiller, et al. v. Dover Area School District, et al. 400 F.Supp.2d 707 (M.D. Pa 2005). District Court for the Middle District of Pennsylvania.

16.For a debate between the advocates of "intelligent design" and responses by natural scientists, social scientists, and the philosopher Barbara Forrest (who 
have responded that the notion of nonmaterial causes which cannot be investigated empirically breaks with the conventions of scientific discourse. Defenders of evolutionary science argue that proponents of intelligent design have not been able to create a program of research based on empirical observations and capable of responding to new data. The proponents of intelligent design have not done any research and thus no articles proving "intelligent design" have been published in peerreviewed journals.

The Discovery Institute might appear to be making a mundane truth claim. Its affiliates argue that the universe is so complicated that Someone must have planned it. In this truth claim, the "intelligent designer" (the god-term) is taken to be immediately present and representation selfevident. However, the truth claim that the universe has an "intelligent designer" is a symbolic one since the "intelligent designer" is known only through the Discovery Institute's representation of that being. The representation constitutes the presentation; the invisible is rendered present through representation. As a symbolic truth claim, "intelligent design" aims to restore coherence and order to a domain regarded as disordered.

In this Christian antievolutionary activity around "intelligent design," symbolic and veridical truth collide, with the symbolic formula of truth attempting to subordinate and colonize the veridical. The deployment of symbolic truth in "intelligent design" would also destabilize the relation between representation and presentation in the veridical formula of truth, as it would not be clear whether scientific representation was of things that were already present or of things that were not present. Where scientists may now participate in spiritual practices outside their scientific work, "intelligent design" would insist that scientists qua scientists find intelligent design in their experiments. Further, the truth formula of science would not simply be the expulsion of error and the production of representations that account for things in their depths. The opposite of veridical truth would no longer be error but incoherence and disorder; or perhaps veridical truth would be subordinated to symbolic truth, responsible for producing an account of the universe as coherent, orderly, and meaningful. Unlike the veridical formula of truth, the enunciatory subject in the symbolic formula forms a necessary bridge between the visible and the invisible. If symbolic truth colonized veridical truth, it would lead to a reconstruction of the latter's formula; a new enunciatory subject, the Discovery Institute and its delegates, would be introduced into the formula of veridical truth, and an enunciated subject, the in-

has been active in the critique of "intelligent design") see Natural History, April 2002, special issue on "Intelligent Design" at http://www.actionbioscience.org/evolution/nhmag.html. Accessed August 2007. 
telligent designer, into its discourse. The effect of these shifts between presentation and representation, truth and non-truth, and the position of the subject would, among other noteworthy changes, be an incoherent formula of truth stretched between the veridical and the symbolic.

The case of antievolutionary thinking shows an instance of an opportunistic use of symbolic truth trying to colonize the veridical formula of truth. While truth formulae may enter into contestation, the presumed limit of which would be to eliminate truth formula, they may also coexist. Thus "intelligent design" does not currently represent the relation of most Christian churches to the theory of evolution. Contemporary Christian churches do not, as a whole, have an antagonistic relation to science, preferring to leave Galileo buried. Thus, although contestation among truth formulae exists in modernity, a generalized model of warfare among truth formulae should not be applied.

Religion and science have had a long and well-known history of clashes since the early modern period. These I analyze here as symbolic and veridical truth formulae. Mundane truth has also long vied with other truth formulae and with sovereign power. The mundane formula of truth acts to protect common knowledge, which, as Gramsci observed, is inconsistent and vulnerable. Where things are immediately present and representation self-evidently adequate to them, the subject may bear witness to direct experience at a distance from the enunciations of power. By way of example, one could point to the interviews by Dr. Megan Boler with online political bloggers critical of the second war in Iraq. The bloggers saw themselves as telling truth in the face of what they called "lies" that were being circulated by the mass media. ${ }^{17}$ In the words of one blogger:

When stationed in Iraq I found a vacuum in the world news that didn't truly reflect what was happening and what we felt. For better or worse I tried to say the truth in what I saw without compromising the security of our mission. (Boler 2006)

In the work of these political bloggers one sees mundane truth based on people's practical moral sense of being lied to. Mundane truth is powerful in democratic practice, holding to account power holders who may be removed from office by the sovereign people. The case of the political bloggers points to the continued existence of ancient parrhesiastistic truth-telling practices, where the truth teller speaks at personal jeopardy to her/himself (Foucault 2001:15-17).

17.Dr. Megan Boler, "Digital Dissent and the Politics of Truth," Biopolitics and Technoscience Seminar, University of Toronto, November 2006. 
The theorization of truth formulae as heterogeneous opens a space for an analysis of truth and power as having variable possible relations rather than being inevitably mutually reinforcing. Governance may operate through endless spirals of truth and power, an apparatus of subjugation, but mundane truth serves as a resource of the lifeworld that may be used either for or against governance and sovereign power. Mundane truth has no necessary alignment with power; it may act as a resource distancing the subject from subjugation. And symbolic truth, never fully of this world, can either secure sovereign power or its critique.

\section{Conclusion}

My observations have been intended to theorize "truth regime" in the spirit of Foucault's last work on the multiplicity of truth games and the negotiated relations between truth and power found in ancient practices of the self. I have argued that the truth regime in modernity is characterized by a number of irreducible and incompatible truth formulae. Each truth formula has three components: a relation between presentation and representation, a relation between truth and non-truth, and the place of the subject in discourse/speech. Four differing formulae of truth are copresent in advanced modernity: veridical, governmental, symbolic, and mundane. These formulae do not form a combinatoire of all possible forms of truth, nor is such a combinatoire possible given the creativity of truth games in the history of the global North. The concept of irreducible, co-present truth formulae enables a more complex appreciation of the historicity of our contemporary truth regime, which is compounded of radically differing truthful knowledges through the separate histories of science, governance, religion/politics/law, and everyday life.

The inclusion of symbolic and common knowledge in the analysis of truth formulae expands and reconstitutes the fundamental problematic of Foucauldian work in modernity: the composition and effects of scientific and governmental knowledge. To reduce our present truth regime to the scientific or quasi-scientific misses the field of differing possible relations across heterogeneous truth formulae. Given the multiplicity of truth formulae, their relations to governance and sovereign power are heterogeneous rather than inevitably enhancing power. If truth is not singular, then neither is its relation to power.

The significance of values other than truth for our present should also be considered. Pierre Hadot (2002:263) has been fond of quoting Plutarch, "[i]t is more important to want the good than it is to know the truth." In this regard it might be remarked that the heartland of Christi- 
anity is the value of love, not truth, with the former leading to a deeper antimaterialism than ever imagined by the Discovery Institute. And Foucault's (2000b:133) observation that "[t]he political question ... is not error, illusion, alienated consciousness, or ideology; it is truth itself" remains seductive but disputable. Let us remember the obvious: polities such as Afghanistan, Canada, Israel, the United Kingdom, and the United States have been made and unmade by forces other than truth. In order to deal with the question of politics and power one must enter a theoretical terrain that intersects with, but goes beyond, truth.

\section{REFERENCES}

Ansell-Pearson, Keith. 1995. The significance of Michel Foucault's reading of Nietzsche: Power, the subject and political theory. Pp. 13-30 in Peter R. Sedgwick, ed., Nietzsche: A Critical Reader. Oxford: Blackwell.

Bachelard, Gaston. 1977. Connaissance commune et connaissance scientifique. Pp. 207-224 in Le Matérialisme rationnel. Paris: Presses Universitaires de France.

Balibar, Étienne. 1993. Science et vérité dans la philosophie de Georges Canguilhem. Pp. 58-76 in Georges Canguilhem: Philosophe, historien des sciences. Paris: Bibliothèque du Collège International de Philosophie, Éditions Albin Michel.

Bauman, Zygmunt. 1989. Modernity and the Holocaust. Ithaca, NY: Cornell University Press.

Brenner, Neil. 1994. Foucault's new functionalism. Theory and Society 23:679-709.

Calhoun, Craig. 2007. Cosmopolitanism and Belonging: From European Integration to Global Hopes. London: Routledge.

Canguilhem, Georges. 1988. Ideology and Rationality in the History of the Life Sciences. Trans. Arthur Goldhammer. Cambridge, MA: MIT Press.

Castel, Robert. 1988. The Regulation of Madness: The Origins of Incarceration in France. Berkeley: University of California Press.

Davidson, Arnold. 2001. On epistemology and archeology: From Canguilhem to Foucault. Pp. 192-206 in The Emergence of Sexuality: Historical Epistemology and the Formation of Concepts. Cambridge, MA and London: Harvard University Press.

Delaporte, François. 1998. Foucault, epistemology and history. Economy and Society 27 (2-3):285-297.

Dreyfus, Hubert and Paul Rabinow. 1983. Michel Foucault: Beyond Structuralism and Hermeneutics. Chicago: University of Chicago Press. 
Dupont, Danica. 2006. Foucault and the French epistemological tradition: An analysis and critique of the archaeological project. $\mathrm{PhD}$ Dissertation, Department of Sociology, Queen's University, Kingston, Canada.

Ericson, Richard V., Aaron Doyle, Dean Barry, eds. 2003. Insurance as Governance. Toronto: University of Toronto Press.

Foucault, Michel. 2001. Fearless Speech. Joseph Pearson, ed. Los Angeles: Semiotext(e).

2000a. Governmentality. Pp. 201-222 in Paul Rabinow, series ed., Essential Works of Foucault 1954-1984. New York: The New Press. Vol. 3 , Power, J.B. Faubion, ed.

2000b. Truth and power. Pp. 111-133 in Paul Rabinow, series ed. Essential Works of Foucault 1954-1984. New York: The New Press. Vol. 3, Power, J.B. Faubion, ed.

1998a. Foucault. Pp. 459-463 in Paul Rabinow, series ed., Essential Works of Michel Foucault, 1954-1984. New York: The New Press. Vol. 2, Aesthetics, Method, Epistemology, James D. Faubion, ed.

1998b. Nietzsche, genealogy, history. Pp. 369-391 in Paul Rabinow, series ed., Essential Works of Michel Foucault, 1954-1984. New York: The New Press. Vol. 2, Aesthetics, Method, Epistemology, James D. Faubion, ed.

1997. The ethics of the concern for self as a practice of freedom. Pp. 281-302 in Paul Rabinow, series ed., Essential Works of Michel Foucault, 1954-1984. New York: The New Press. Vol 1, Ethics, Subjectivity and Truth, Paul Rabinow, ed.

1994a [1977]. Entretien avec Michel Foucault. Pp. 140-160 in Dits et écrits, 1954-1988. Paris: Gallimard, Vol. 3.

1994b [1980]. La Poussière et le nuage. Pp. 10-19 in Dits et écrits, 1954-1988. Paris: Gallimard, Vol. 4.

1994c [1980]. Table ronde du 20 mai 1978. Pp.20-34 in Dits et écrits, 1954-1988. Paris: Gallimard, Vol. 4.

1994d. Titres et travaux. Pp. 842-846 in Dits et écrits, 1954-1988. Paris: Gallimard, Vol. 1.

1989a. Introduction. Pp. 7-24 in Georges Canguilhem, On the Normal and the Pathological. New York: Urzone.

1989b [1966]. The Order of Things. London and New York: Routledge. 1986. The History of Sexuality. Vol. 2, The Use of Pleasure, Robert Hurley, trans. New York: Vintage Books.

1979 [1975]. Discipline and Punish. Alan Sheridan, trans. New York: Vintage.

1978 [1976]. The History of Sexuality. Vol 1. An Introduction. Robert Hurley trans. New York: Pantheon.

1976a [1969]. The Archaeology of Knowledge, Alan M. Sheridan Smith trans. New York: Harper Colophon.

1976b [1971]. The discourse on language. Pp. 215-237 in Alan M. Sheridan Smith, trans., The Archaeology of Knowledge. New York: Harper Colophon.

1973 [1963]. The Birth of the Clinic. Alan M. Sheridan Smith, trans. New York: Vintage. 
Fraser, Nancy. 2005. Reframing justice in a globalizing world. New Left Review $36: 69-88$.

Goffman, Erving. 1961. Asylums: Essays on the Social Situation of Mental Patients and Other Inmates. Garden City, NY: Anchor Books.

Good, Byron J. 1994. Medicine, Rationality, and Experience. Cambridge: Cambridge University Press.

Hacking, Ian. 2004. Between Michel Foucault and Erving Goffman: Between discourse in the abstract and face-to-face interaction. Economy and Society 33(3):277-302.

Hadot, Pierre. 1995. Philosophy as a Way of Life. Michael Chase trans. Oxford: Blackwell.

Han, Béatrice. 2002. Foucault's Critical Project: Between the Transcendental and the Historical. Stanford: Stanford University Press.

Heritage, John. 1984. Garfinkel and Ethnomethodology. Cambridge: Polity.

Hopwood, Anthony G. and Peter Miller, eds. 1994. Accounting as Social and Institutional Practice. Cambridge: Cambridge University Press.

Joas, Hans. 2000. The Genesis of Values. Chicago: University of Chicago Press.

Kleinman, Arthur. 1988. The Illness Narratives: Suffering, Healing, and the Human Condition. New York: Basic Books.

Lefort, Claude. 1988. Democracy and Political Theory. Cambridge: Polity. 1986. The Political Forms of Modern Society. Boston: MIT Press.

Léonard, Jacques. 1980. L'Historien et le philosophe: A propos de Surveiller et punir: naissance de la prison. Pp. 9-28 in Michelle Perrot, ed., L'Impossible Prison: Recherches sur le système pénitentiaire au XIXe siècle. Paris: Éditions du Seuil.

Nietzsche, Friedrich. 1979. Philosophy and Truth, Daniel Breazeale trans. Amherst, NY: Humanity Books.

Osborne, Thomas. 1998. Aspects of Enlightenment: Social Theory and the Ethics of Truth. Lanham, MD: Rowman and Littlefield..

Rapp, Rayna. 1999. Testing Women, Testing the Fetus: The Social Impact of Amniocentesis in America. New York: Routledge.

Rose, Nikolas. 1999. Powers of Freedom. Cambridge: Cambridge University Press.

1990. Governing the Soul: The Shaping of the Private Self. London and New York: Routledge.

Rose, Nikolas, Pat O'Malley, and Mariana Valverde. 2006. Governmentality. Annual Review of Law and Social Science 2:83-104.

Schutz, Alfred. 1962. On multiple realities. Pp. 207-229 in Collected Papers. The Hague: Martinus Nijhoff. Vol 1. 
Shapin, Steven. 1994. A Social History of Truth. Chicago and London: University of Chicago Press

Singer, Brian and Lorna Weir. 2007. Politics and sovereign power: Considerations on Foucault. European Journal of Social Theory 9(4):443-465.

Taylor, Dianna and Karen Vintges, eds. 2004. Feminism and the Final Foucault. Urbana and Chicago: University of Illinois Press

Tiles, Mary. 1984. Bachelard: Science and Objectivity. Cambridge: Cambridge University Press.

Valverde, Mariana. 2004a. Experience and truth telling in a post-humanist world: A Foucauldian contribution to feminist ethical reflections. Pp. 67-90 in Dianna Taylor and Karen Vintges, eds, Feminism and the Final Foucault. Urbana and Chicago: University of Illinois Press. 2004b. Law's Dream of a Common Language. Princeton, NJ and Oxford: Princeton University Press. 1998. Diseases of the Will: Alcohol and the Dilemmas of Freedom. Cambridge: Cambridge University Press. 
